\title{
Penerapan Media Story Picture Untuk Meningkatkan Motivasi Belajar Siswa Dalam Pembelajaran Pendidikan Kewarganegaraan
}

\author{
Ajat Sudrajat \\ SMP Negeri 1 Cikoneng \\ ajat2342@gmail.com
}

\begin{abstract}
This research was motivated by the results of preliminary observations in class VIII of Cikoneng 1 State Middle School in Ciamis Regency which had several problems during the learning process. One of them is the low learning motivation of students in PPKn subjects, it is seen that teaching and learning activities students tend to feel bored and do activities outside of PPKn learning. This requires the teacher to make innovation and creativity in learning. The approach used in this study is a qualitative approach. The method used in this study is a classroom action research method. The main objective is to encourage teachers to take action in dealing with problems in the learning process. Whereas the subject of the research is the eighth grade students. The results obtained were 1) the initial condition of PPKn learning before the media story picture was applied, there were no students who were active when the learning took place, and the teacher still dominated the class with the lecture method. 2) the implementation of learning by using media story picture. The implementation of learning using media story picture is carried out through three cycles, in each cycle students are divided into several groups then each group discusses the story picture given by the teacher with the questions that have been provided, and discusses problem solving contained in the media. 3) Increased student learning motivation through media story picture, through actions taken in class VIII produces a positive impact, because students are required to read and understand the material of implementing democracy in various aspects of life by analyzing the material students can understand the nature of democracy and various kinds of democracy and provide examples of various things that occur in everyday life about the material, especially in cases that occur in Indonesia. Students better understand the concept and can also recall concepts that have been explained by the teacher, thus students are able to find a deeper understanding through the story in the story picture. 4) Advantages and constraints and solutions to the PPKn learning process by using media story pictures, increasing motivation, reading interest and students 'curiosity towards PPKn learning, increasing student learning outcomes, increasing students' understanding of concepts, increasing student activity in the learning process.
\end{abstract}

Keywords - Media Story Picture, Motivation, Learning.

Abstrak : Penelitian ini dilatarbelakangi oleh hasil observasi awal di kelas VIII SMP Negeri 1 Cikoneng Kabupaten Ciamis yang memiliki beberapa masalah pada saat proses pembelajaran. Salah satunya yaitu rendahnya motivasi belajar siswa pada mata pelajaran PPKn, hal tersebut terlihat kegiatan belajar mengajar siswa cenderung merasa bosan dan melakukan aktifitas di luar pembelajaran PPKn. Hal tersebut menuntut guru untuk membuat inovasi dan kreatifitas dalam pembelajaran. Pendekatan yang digunakan dalam penelitian ini adalah pendekatan kualitatif. Metode yang digunakan dalam penelitian ini adalah metode penelitian tindakan kelas. Tujuan utama adalah mamacu guru untuk melakukan tindakan dalam menangani permasalahan dalam proses pembelajaran. Sedangkan yang menjadi subyek penelitian ialah siswa kelas VIII. Hasil penelitian yang diperoleh adalah 1) Kondisi awal pembelajaran PPKn sebelum diterapkan media story picture, tidak ada siswa yang aktif saat pembelajaran berlangsung, serta guru masih mendominasi di kelas dengan metode ceramah. 2) pelaksanaan pembelajaran dengan menggunakan media story picture. Pelaksanaan pembelajaran dengan menggunakan media story picture dilaksanakan melalui tiga siklus, pada setiap siklus siswa dibagi kedalam beberapa kelompok kemudian setiap kelompok mendiskusikan story picture yang diberikan oleh guru dengan pertanyaan yang sudah disediakan, serta mendiskusikan pemecahan masalah yang terdapat dalam media. 3) Peningkatan motivasi belajar siswa melalui media story picture, melalui tindakan yang dilaksanakan di kelas VIII menghasilkan dampak positif, karena siswa dituntut untuk membaca dan memahami materi pelaksanaan demokrasi dalam berbagai aspek kehidupan dengan menganalisis materi tersebut siswa dapat memahami hakikat demokrasi dan macammacam demokrasi serta memberikan contoh berbagai hal yang terjadi dalam kehidupan sehari-hari mengenai materi tersebut terutama dalam kasus-kasus yang terjadi di Indonesia. Siswa lebih memahami konsep dan juga dapat mengingat kembali konsep-konsep yang telah dijelaskan oleh guru, dengan demikian siswa mampu menemukan pemahaman yang lebih mendalam melalui cerita dalam story picture tersebut. 4) Keunggulan dan kendala serta solusi proses pembelajaran PPKn dengan menggunakan media story picture, meningkatnya motivasi, minat membaca dan rasa ingin tahu siswa terhadap pembelajaran PPKn, meningkatnya hasil belajar siswa, meningkatnya pemahaman konsep siswa, meningkatnya aktivitas siwa dalam proses pembelajaran.

Kata Kunci : Media Story Picture, Motivasi, Belajar. 


\section{Pendahuluan}

Tidak dapat dipungkiri bahwa mata pelajaran PPKn di sekolah seringkali dianggap sebagai mata pelajaran yang membosankan, sehingga banyak siswa yang menganggap mata pelajaran PPKn ini sebagai mata pelajaran yang tidak penting. Dampaknya adalah banyak siswa yang ketika mata pelajaran PPKn berlangsung, kurang adanya motivasi dalam pembelajaran ini.Padahal patut kita ingat bahwa pelajaran PPKn sangat penting dalam membentuk karakter siswa itu sendiri. Oleh karena itu dibutuhkan pemecahan masalah agar pembelajaran PPKn di sekolah dapat berlangsung dengan kondusif dan memotivasi siswa untuk antusias dalam kegiatan belajar khususnya dalam mata pelajaran PPKn.

Dalam mata pelajaran PPKn berisi materi-materi mengenai moral, menjadi warga Negara yang baik dan yang lainnya. Selain berisikan materi-materi, pembelajaran PPKn pun menanamkan sikap nasionalisme pada siswa untuk saat ini dan untuk masa yang akan datang, karena tidak dapat kita pungkiri bahwa PPKn membentuk generasi penerus bangsa yang mempunyai moral dan jiwa yang nasionalisme.

Jika melihat kembali pada realita yang ada, bahwa dalam pembelajaran PPKn guru seringkali mengandalkan LKS (Lembar Kerja Siswa) dalam setiap pertemuannya. Oleh karena itu dirasa bahwa jika kegiatan itu dilakukan secara terus-menerus akan membuat siswa menjadi tidak efektif dalam pembelajaran PPKn, dan tidak menutup kemungkinan sebagian siswa yang mengerjakan dengan hasil kerja orang lain. Salah satu dampak dari penggunaan LKS sebagai acuan untuk siswa. Selain LKS, kita pula bisa melihat sejenak pada pola mengajar guru yang monoton. Pengadaan media seperti infokus pun seakan menjadi hal yang mewah bagi sebagian sekolah.

Mengingat tidak semua sekolah menyediakan fasilitas tersebut. Padahal jika kita menilik pada penggunaan media Power Point cukup membantu karena untuk mempermudah penyajian materi. Seperti halnya sudah biasa kita lihat guru PPKn yang mengajar dan menjelaskan materi PPKn dengan ceramah di depan kelas. Dampaknya membuat siswa menjadi jenuh, dan tak jarang pula yang menjadi mengantuk yang akibatnya materi pembelajaran PPKn pun menjadi tidak efektif untuk para siswa. Terlebih keberadaan buku teks pun sangat jarang digunakan para siswa dalam pembelajaran PPKn. Bisa diperkirakan dan menilai bahwa pembelajaran PPKn di persekolahan ini harus segera dibenahi dengan berbagai media pembelajaran yang tentunya efektif.

Apabila melihat dari realita, siswa cenderung pasif dalam setiap pembelajara PPKn. Dapat disimpulkan sendiri bahwa penyebab dari siswa yang pasif dalam pembelajaran PPKn adalah faktor guru PPKn itu sendiri. Terlebih lagi yang menjadi pendukung kurangnya antusiasme siswa dalam pembelajaran PPKn adalah seringkali pelajaran PPKn yang dijadwalkan di jam akhir persekolahan. Dampaknya stamina belajar siswa sudah menurun karena sudah sejak pagi mengikuti kegiatan belajar mengajar.

Dapat simpulkan bahwa faktor penyebab kurang efektifnya pembelajaran PPKn di sekolah adalah pola pembelajaran guru yang digunakan. Selain itu anggapan yang dirasa telah melekat pada siswa bahwa pelajaran PPKn itu suatu mata pelajaran yang membosankan, dan sering dianggap sebagai mata pelajaran yang kurang penting. Dampaknya tentunya berujung pada pembelajaran PPKn yang kurang efektif.

Pada tanggal 30 Januari 2018 peneliti melakukan observasi awal terhadap kelas VIII G di SMP Negeri 1 Cikoneng Kabupaten Ciamis Ketika proses pembelajaran berlangsung, terlihat hanya beberapa siswa yang mengikuti pembelajaran dengan baik. Diantaranya ketika guru sedang menjelaskan, siswa terlihat tidak semangat dan cenderung mempunyai kegiatan sendiri. Selain itu pada saat guru memberikan pertanyaan, hanya beberapa siswa yang berpartisipasi. Sekian banyak permasalahan, penelitian ini lebih memfokuskan pada motivasi siswa dalam pembelajaran PPKn dengan menerapkan media Story Picture dalam pembelajaran PPKn. Dalam proses pembelajaran PPKn dibutuhkan partisipasi yang tinggi, karena dengan banyaknya partisipasi siswa dalam pembelajaran PPKn akan membuat pembelajaran lebih menarik. Dalam penerapan media Story Picture ini, guru dituntut lebih kreatif dalam setiap penyajian materi. Materi yang disampaikan dalam bentuk cerita gambar (story picture) yang dalam penerapannya sangat menarik dengan tidak mengurangi fokus materi yang disampaikan.

Penerapan media ini dilakukan dengan cara Penelitian Tindakan Kelas (PTK),yakni salah satu jenis penelitian terhadap pembelajaran dikelas, yang dimaksudkan untuk mengkaji dan memberikan solusi terhadap berbagai permasalahan yang terjadi dan dialami oleh guru dalam hubungannya dengan situasi kelas (Dunkin and Biddle; Hopkins, 1993) yang pelaksanaannya bersifat kontekstual dan sangat bergantung pada realita sosial di kelas. Atas dasar ini, maka penelitian tindakan kelas menempatkan sentralitas dan otonomi profesionalitas guru dalam proses refleksi terhadap kinerja dan aktivitas mengajarnya.

Berdasarkan pemaparan di atas, maka peneliti tertarik untuk lebih memperdalam kajian mengenai penerapan media story picture menjadi sebuah penelitian. Adapun judul yang peneliti angkat dalam penelitian ini adalah " PENERAPAN MEDIA STORY PICTURE UNTUK MENINGKATKAN MOTIVASI BELAJAR SISWA DALAM PEMBELAJARAN PPKN (Penelitian Tindakan Kelas Terhadap Siswa di Kelas VIII G SMP Negeri 1 Cikoneng Kabupaten Ciamis) ".

Berdasarkan latar belakang di atas, dapat disimpulkan bahwa pembelajaran PPKn di SMP Negeri 1 Cikoneng Kabupaten Ciamis tidak menggunakan media yang memadai. Guru tidak menggunakan media yang memudahkan siswa dalam menerima pembelajaran. Alat bantu lain pun tidak tersedia di sekolah tersebut, yang pada 
akhirnya terdapat masalah dalam pembelajaran PPKn yaitu kurangnya motivasi siswa dalam kegiatan belajar mengajar PPKn. Maka dapat dirumuskan masalah sebagai berikut:

1. Bagaimana kondisi awal pembelajaran PPKn di kelas VIII G SMP Negeri 1 Cikoneng Kabupaten Ciamis sebelum diterapkan media story picture?

2. Bagaimana penerapan media Story Picture untuk meningkatkan motivasi belajar siswa kelas VIII G?

3. Apa kendala yang dihadapi dalam penerapan media Story Picture di kelas VIII G di SMP Negeri 1 Cikoneng Kabupaten Ciamis dalam meningkatkan motivasi belajar siswa?

4. Apa upaya untuk mengatasi kendala yang dihadapi dalam penerapan media Story Picture untuk meningkatkan motivasi belajar siswa?

Berdasarkan rumusan masalah yang diajukan pada penelitian ini maka tujuan yang hendak dicapai dalam penelitian ini adalah sebagai berikut:

1. Tujuan umum

Tujuan umum dari penelitian ini adalah untuk mengetahui peningkatan motivasi siswa dalam pembelajaran PPKn dengan penerapan media Story Picture.

2. Tujuan Khusus

Tujuan khusus dari penelitian ini adalah untuk menganalisis :

a. Kondisi awal pembelajaran PPKn di kelas VIII G SMP Negeri 1 Cikoneng Kabupaten Ciamis sebelum diterapkan media story picture.

b. Penerapan media Story Picture untuk meningkatkan motivasi belajar siswa kelas VIII G dalam pembelajaran PPKn.

c. Kendala yang dihadapi dalam menerapkan media Story Picture di kelas VIII G di SMP Negeri 1 Cikoneng Kabupaten Ciamis untuk meningkatkan motivasi belajar siswa.

d. Upaya yang dilakukan untuk mengatasi kendala yang dihadapi dalam menerapkan media Story Picture untuk meningkatkan motivasi belajar siswa.

Berdasarkan tujuan penelitian di atas, maka peneliti mengharapkan penelitian ini bermanfaat sebagai berikut :

a) Bagi guru :

1) Mendorong para guru untuk mengkaji media Story Picture sebagai suatu alternatif menarik dalam meningkatkan motivasi siswa di sekolah.

2) Untuk memperbaiki proses pembelajaran khususnya dalam mata pelajaran PPKn jika ditemui adanya kesulitan dari faktor di lapangan khususnya dalam penerapan media Story Picture, sehingga dapat meningkatkan motivasi belajar siswa dalam pembelajaran PPKn.

b) Bagi Siswa :

1) Meningkatkan motivasi siswa dalam proses belajar mengajar dikelas.

2) Membantu siswa dalam mengatasi permasalahan dalam belajar baik dengan diri sendiri maupun dengan orang lain.

3) Meningkatkan pola interaksi yang beragam antara siswa dengan siswa ataupun antara guru dengan siswa.

4) Meningkatkan sikap berani berpendapat dalam kegiatan belajar mengajar PPKn

c) Bagi Sekolah:

1) Sekolah dapat mengoptimalkan sumber daya yang tersedia untuk memajukan sekolahnya melalui penerapan media pembelajaran.

2) Sekolah diharapkan mampu mencermati kebutuhan peserta didik yang bervariasi baik itu dari segi harapan masyarakat terhadap sekolah maupun tuntutan dunia kerja untuk memperoleh mutu lulusan yang berguna.

d) Bagi Peneliti

Manfaat yang didapat bagi peneliti adalah sebagai salah satu pengalaman yang di dapat dalam menerapkan media Story Picture ini khususnya.

\section{METODE PENELITIAN}

\section{A. Setting dan Subjek Penelitian}

Lokasi yang dijadikan tempat penelitian adalah SMP Negeri 1 Cikoneng Kabupaten Ciamis.

Pada penelitian ini yang menjadi subyek penelitian adalah siswa kelas VIII G SMP Negeri 1 Cikoneng Kabupaten Ciamis. Jumlah siswa yang menjadi sasaran penelitian adalah 33 orang siswa perempuan bersama guru mitra. Alasan pemilihan kelas VIII G karena guru mitra yang merekomendasikan kelas tersebut dijadikan sebagai subyek penelitian, Kelas tersebut adalah kelas yang mempunyai motivasi kurang dalam pembelajaran PPKn dibandingkan dengan kelas yang lainnya.

Adapun waktu pelaksanaan penelitian dilaksanakan pada semester genap tahun pelajaran 2017/2018 adapun rincian pelaksanaan penelitian yaitu 2 siklus 4 pertemuan.

Pelaksanaan kegiatan dapat dilaksanakan sebagai berikut:

1. Persiapan penelitian, tanggal 08 Januari 2018,

2. Perijinan penelitian dari Kepala Sekolah, tanggal 22 Januari 2018,

3. Pelaksanaan penelitian sebagai berikut :

a) Siklus I dilaksanakan Selasa 06 Februari 2018,

b) Siklus II dilaksanakan Selasa 13 Februari 2018,

c) Siklus III dilaksanakan Selasa 20 Februari 2018,

4. Pengolahan hasil penelitian, tanggal 23 Februari 2018,

5. Seminar hasil penelitian, tanggal 10 Maret 2018,

6. Pelaporan hasil penelitian, tanggal 20 Maret 2018.

\section{B. Prosedur Penelitian}

Prosedur dalam penelitian ini meliputi persiapan penelitian, perizinan penelitian dan tahap pelaksanaan penelitian 


\section{Teknik Pengumpulan Data}

Adapun alat pengumpul data yang digunakan yaitu wawancara, observasi dan studi dokumentasi.

\section{Analisis Data}

Analisis data dilakukan sejak sebelum memasuki lapangan, saat di lapangan sampai selesai di lapangan. Nasution dalam Sugiono ( 2005: 89) menyatakan bahwa ,analisis telah mulai sejak merumuskan dan menjelaskan masalah, sebelum terjun ke lapangan, dan berlangsung terus sampai penulisan hasil penelitian ${ }^{\text {ee }}$. Dalam proses analisis data penulis menggunakan reduksi data, penyajian data dan penarikan kesimpulan.

\section{HASIL PENELITIAN DAN PEMBAHASAN}

\section{A. Pelaksanaan Pembelajaran PPKn Dengan Menggunakan Media Story Picture}

Penerapan media story picture merupakan salah satu media yang dapat meningkatkan motivasi belajar siswa di kelas VIII G yang memiliki motivasi belajar yang rendah. Penerapan media story picture ini dilaksanakan melalui tiga siklus yaitu siklus I dilaksanakan pada hari Sabtu tanggal 06 Februari 2018 materi yang dibahas mengenai pelaksanaan demokrasi dalam berbagai aspek kehidupan yaitu "hakikat demokrasi dan macam-macam demokrasi", siklus II dilaksanakan pada hari Selasa tanggal 13 Februari 2018 dengan materi "kehidupan yang demokratis dalam bermasyarakat, berbangsa dan bernegara", dan pada siklus III dilaksanakan hari Selasa tanggal 20 Februari 2018 dengan materi "sikap positif terhadap pelaksanaan demokratis dalam berbagai kehidupan".

Analisis yang diperoleh oleh peneliti pada penelitian ini didasarkan pada temuan-temuan yang didapat saat penelitian di lapangan yaitu berupa data yang terkumpul baik dari hasil wawancara, observasi, catatan lapangan, dan studi dokumentasi yang dimulai saat observasi awal, siklus I, siklus II sampai siklus III. Berdasarkan hasil pengamatan yang dilakukan oleh peneliti di lapangan, penerapan media story picture mampu meningkatkan motivasi belajar siswa pada mata pelajaran Pendidikan Kewarganegaraan (PPKn).

Tahap awal pelaksanaan siklus I guru mitra masih merasa canggung dalam penerapan media story picture dikarenakan media story picture dapat dikatakan sebagai media baru yang digunakan guru mitra dalam proses pembelajaran. Meskipun demikian guru mitra akhirnya bisa mempergunakan dengan baik pada siklus berikutnya. Pada siklus I respon siswa sudah terlihat antusias dalam proses pembelajaran ketika guru membagikan story picture. Namun pada saat diskusi masih banyak siswa yang mengobrol, bermain Handphone dan kegiatan lainnya di luar pembelajaran. Hal tersebut kemudian menjadi perbaikan dalam pelaksanaan siklus II.
Pada tahap pelaksanaan siklus II guru mitra membagi kelompok sama seperti pada pelaksanaan siklus I dikarnakan agar siswa dapat lebih bekerja sama masingmasing anggotanya. Hal tersebut membawa dampak pada aktivitas dan motivasi siswa saat proses pembelajaran meskipun tidak terlalu terlihat perubahannya karena siswa yang berpendapat, bertanya dan menanggapi masih siswa yang itu-itu saja dan masih banyak siswa yang mengandalkan temannya meskipun siswa yang mengobrol dan bermain Handphone sudah tidak terlihat. Hal itu pula menjadi perbaikan dalam pelaksanaan siklus III.

Pada pelaksanaan siklus III guru tetap membagi siswa ke dalam kelompok sebelumnya. Pada pelaksanaan siklus III ini setiap kelompok menghasilkan satu buah story picture dengan pembahasan yang berbeda-beda setiap kelompoknya. Hal tersebut membuat perubahan pada aktivitas belajar siswa, siswa lebih berkonsentrasi dan termotivasi lagi ketika tanya jawab berlangsung setiap siswa berlomba-lomba bertanya, dan menjawab serta menganggapi berbagai pertanyaan yang muncul saat diskusi berlangsung. Pelaksanaan siklus III ini berjalan dengan baik sesuai dengan apa yang diharapkan oleh guru mitra dan peneliti.

Berdasarkan analisis dan temuan-temuan di lapangan saat pelaksanaan pembelajaran PPKn menggunakan media story picture yang telah dilakukan pada siklus I, II, dan III menunjukkan peningkatan motivasi belajar siswa yang terus meningkat pada setiap siklusnya terutama pada siklus III.

Berdasarkan hasil wawancara tersebut dapat disimpulkan bahwa dalam pelaksanaan penerapan media story picture memberikan perubahan pada proses pembelajaran PPKn dan memudahkan guru mitra dalam menyampaikan materi Pelaksanaan demokrasi dalam berbagai aspek kehidupan serta membuat siswa lebih termotivasi dan mudah memahami materi.

\section{B. Peningkatan Motivasi Belajar Siawa Melalui Media Story Picture}

Media cerita bergambar dalam pembelajaran merupakan rangkaian kegiatan/cerita yang disajikan secara berurutan kemudian siswa dilatih mengungkapkan adegan dan kegiatan tersebut yang apabila dirangkaikan akan menjadi suatu cerita terkait dengan materi yang disampaikan. Gambar dalam cerita akan lebih menarik lagi jika didasarkan khususnya pada kegiatan kehidupan siswa tanpa mengurangi isi dari materi yang disampaikan. Media cerita bergambar merupakan salah satu media yang tepat yang dapat digunakan untuk menstimulus kemauan dan kemampuan membaca nyaring pada siswa.

Media story picture merupakan salah satu upaya yang digunakan untuk memotivasi siswa dalam belajar. Peningkatan motivasi belajar pada siswa kelas VIII G dilihat dari aktivitas siswa dalam pembelajaran serta mengerjakan tugas-tugas yang diberikan guru mitra. Aktivitas siswa 
yang dianalisis peneliti dilaksanakan mulai dari siklus I sampai pada siklus III dapat dikatakan mengalami perubahan disetiap siklusnya. Hal tersebut dapat dilihat dari tabel dibawah ini:

TABEL 1

AKTIVITAS BELAJAR SISWA PADA SIKLUS I, II DAN III

\begin{tabular}{|c|c|c|c|}
\hline \multirow{2}{*}{$\begin{array}{c}\text { Aktivitas } \\
\text { Pembelajaran }\end{array}$} & \multicolumn{3}{|c|}{ Persentase (\%) } \\
\cline { 4 - 4 } Bertanya & Siklus I & Siklus II & Siklus III \\
\hline Menjawab & \multirow{2}{*}{$21,21 \%$} & $42,42 \%$ & $69,69 \%$ \\
\hline Menanggapi & & & \\
\hline
\end{tabular}

Berdasarkan tabel di atas dapat dibandingkan peningkatan aktivitas belajar siswa dari setiap siklus dengan menggunakan media story picture, maka dapat dilihat pada grafik dibawah ini

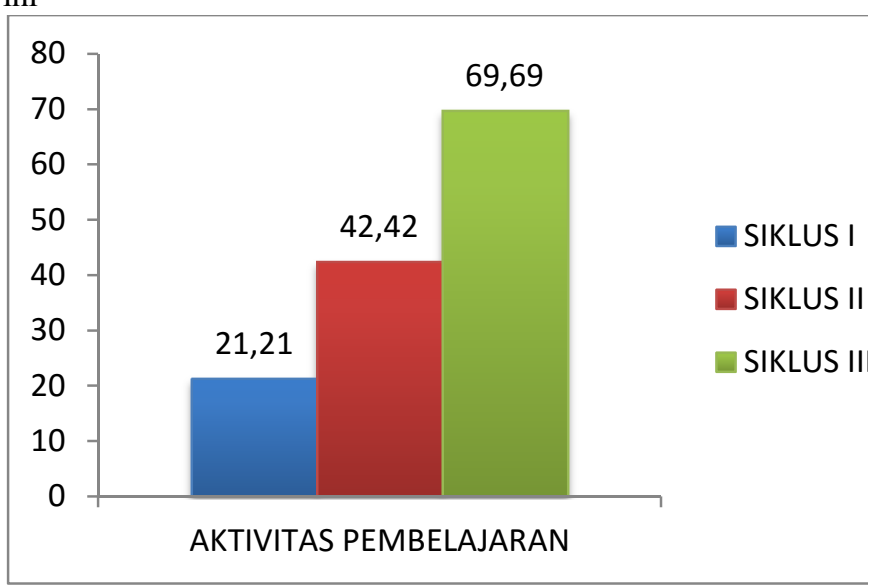

Gambar 1. Aktivitas Belajar Siswa Pada Siklus I, II dan III

Berdasarkan tabel tersebut dapat disimpulkan bahwa aktivitas siswa pada proses pembelajaran mengalami peningkatan pada setiap siklus. Pada siklus I siswa yang bertanya, menjawab, dan menanggapi terlihat sangat kurang yakni hanya $21,21 \%$ saja siswa yang berpartisipasi, perubahan kemudian terjadi pada siklus II sudah terlihat peningkatan siswa yang bertanya, menjawab, dan menanggapi yakni $42,42 \%$ meningkat dibandingkan pada siklus II. Perubahan pada siklus III terlihat menunjukkan hasil yang diinginkan dalam penerapan media komik. Setidaknya 69,69\% aktivitas belajar siswa meningkat, lebih dari setengahnya siswa terlihat aktif dalam pembelajaran.

Selain itu, penulis juga mewawancarai beberapa siswa mengenai penerapan media story picture dalam pembelajaran PPKn. Sebagian besar siswa menjawab menyukai penggunaan media story picture. Siswa menganggap bahwa penggunaan media story picture membuat siswa memahami materi dengan mudah. Hal tersebut dapat dilihat dari tabel triangulasi peneliti, subjek penelitian, dan objek penelitian sebagai berikut:

TABEL 2

SUBJEK PENELITIAN

\begin{tabular}{|c|c|}
\hline GURU & SISWA \\
\hline 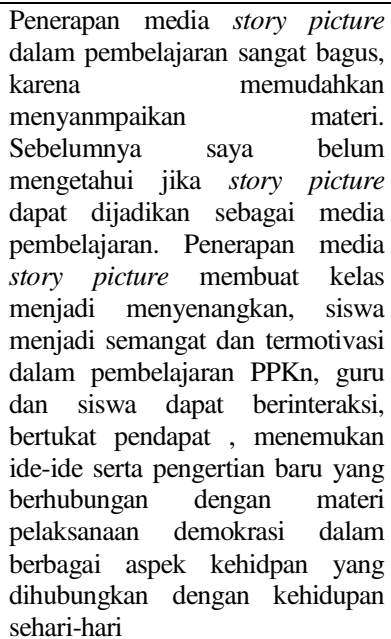 & 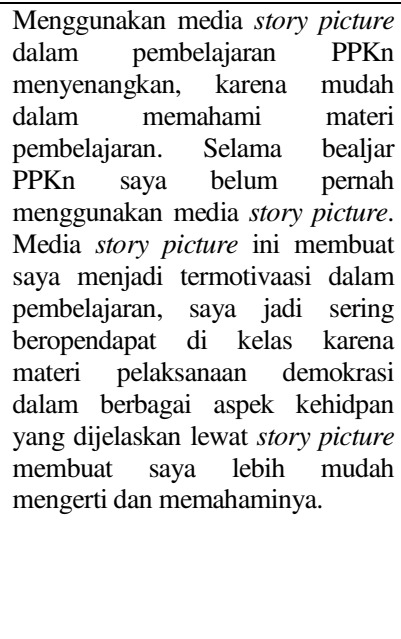 \\
\hline
\end{tabular}

Berdasarkan hasil wawancara di atas, dapat disimpulkan beberapa implikasi dari penerapan media story picture terhadap motivasi belajar siswa, yaitu :

a. Meningkatkan motivasi, minat, dan rasa ingin lebih mendalamai pembelajaran PPKn. Melalui media story picture siswa yang menganggap pembelajaran PPKn membosankan dan kurang penting, menjadi lebih ingin tahu sehingga dapat menanggapi masalah yang berhubungan dengan materi akan semakin menarik.

b. Meningkatkan pemahaman konsep/materi, luasnya materi dan konsep-konsep pada mata pelajaran PPKn seringkali membuat siswa menjadi jenuh dan enggan untuk belajar PPKn seingga sibuk dengan hal lain ketika pembelajaran berlangsung. Dengan penggunaan media story picture siswa menjadi tertarik untuk mengikuti pembelajaran serta aktif dalam proses pembelajaran tersebut.

c. Meningkatkan hasil belajar, dengan adanya motivasi dalam belajar dan kemudahan dalam memahami materi akan membuat hasil belajar siswa menjadi baik pula, karena materi yang ada di story picture lebih mudah dipahami dan diingat oleh siswa.

d. Menguatkan pengetahuan, dalam pelajaran PPKn lebih sering difokuskan pemahaman materi dan konsep-konsep saja, implikasi materi dalam kehidupan sehari-hari jarang dikuatkan dalam proses pembelajaran. Melalui media story picture materi PPKn disajikan dalam bentuk cerita kehidupan seharihari. Sehingga menambah pengetahuan siswa dalam pelajaran PPKn.

Peningkatan lain juga terlihat pada temuan-temuan yang didapatkan saat penelitian berlangsung pada guru dan siswa. Temuan saat pelaksanaan penerapan media story picture pada guru dapat dilihat pada tabel di bawah ini: TABEL 3

KEGIATAN GURU DALAM PENERAPAN MEDIA STORY PICTURE 


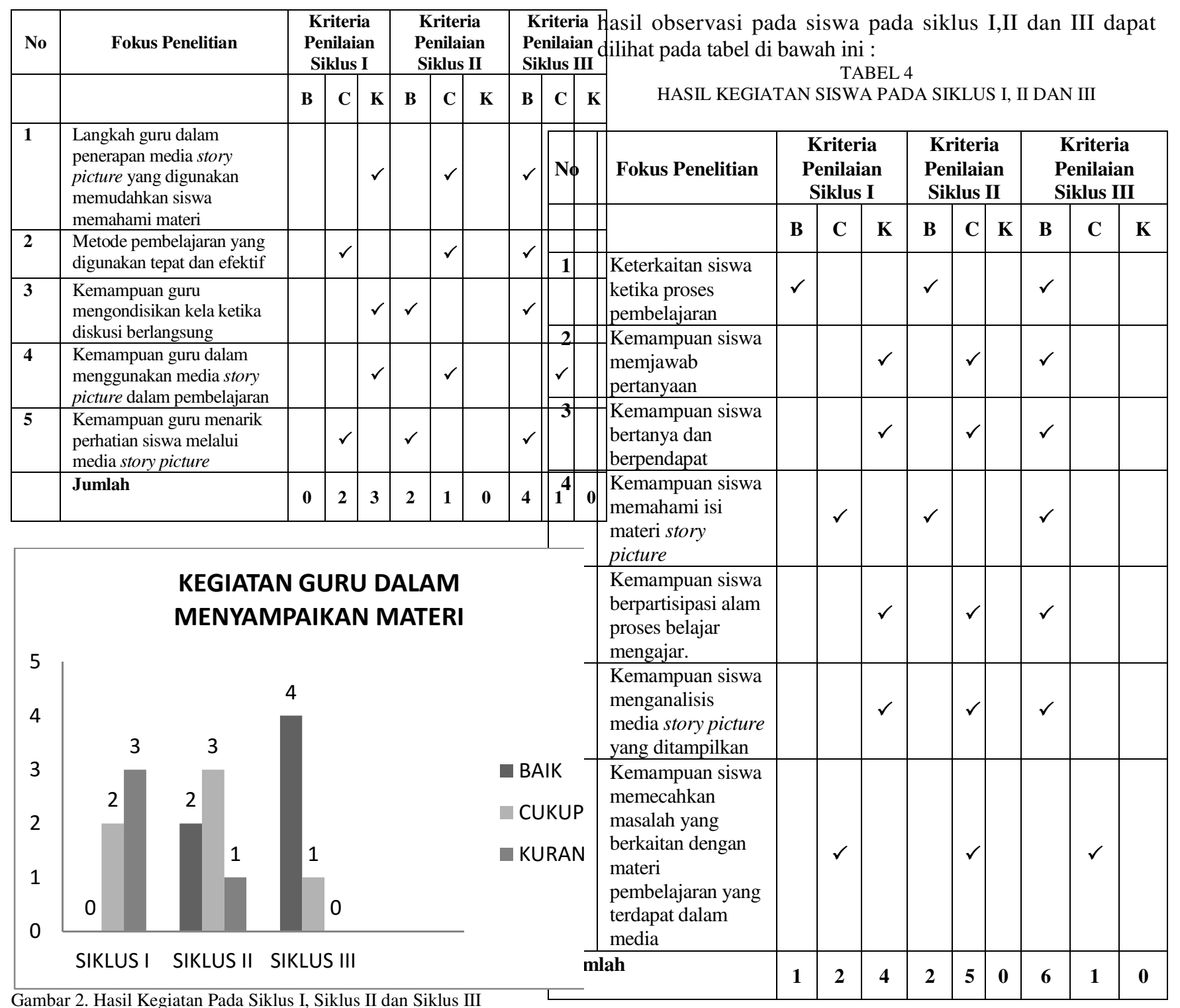

Berdasarkan table dan gerafik di atas dapat disimpulkan bahwa kemampuan guru dalam menerapkan media story picture, pada siklus I kemampuan guru dapat dikatakan masih kurang hal tersebut karena guru masih belum terbiasa menggunakan story picture sebagai media pembelajaran di kelas. Guru masih belum bisa mengkondisikan kelas, sehingga kurang kondusif saat pembelajaran berlangsung. Pada siklus II kemampuan guru cukup meningkat dibandingkan pada siklus I. Guru sudah bisa menempatkan dirinya di kelas, selain itu guru juga dapat mengkondisikan kelas saat siswa berdiskusi mengenai materi yang menjadi pokok bahasan pada pertemuan saat itu. Pada siklus III kemampuan guru dapat dikatakan baik karena guru sudah terbiasa dalam menggunakan media story picture serta dapat memposisikan dirinya dengan baik di kelas. Sedangkan

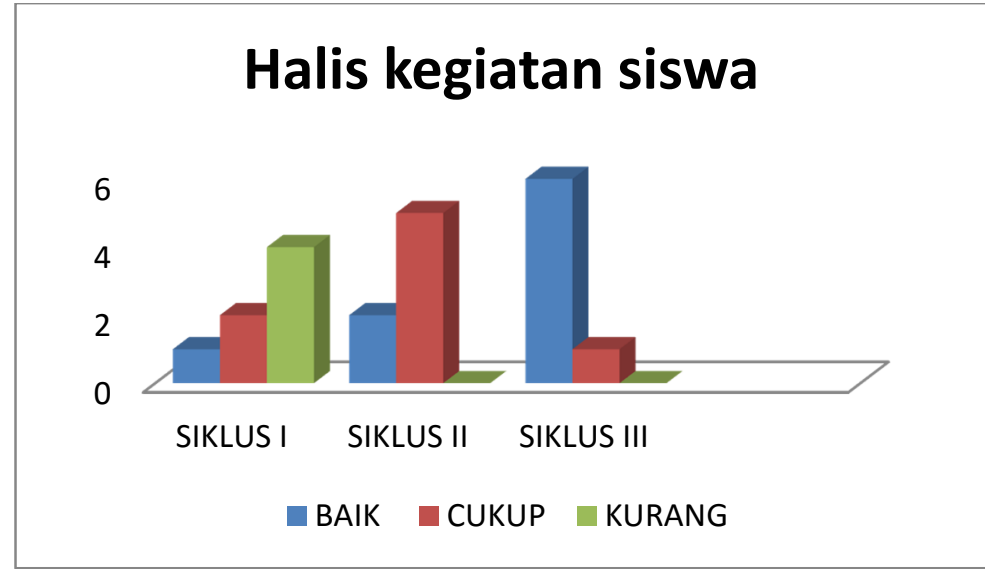

Gambar 3. Hasil kegiatan siswa pada siklus I, siklus II, dan siklus III

Berdasarkan table dan grafik di atas dapat disimpulkan bahwa penggunaan media story picture dalam pelajaran 
PPKn mengalami perubahan yang signifikan pada siswa mulai dari siklus I sampai dengan siklus III. Hal tersebut terjadi karena dengan menggunakan media story picture pelajaran PPKn menjadi mudah dipahami oleh siswa. Siswa menjadi tertarik belajar PPKn, sehingga media story picture meningkatkan motivasi belajar siswa.

Adapun aktivitas siswa dalam mengerjakan diskusi kelompok pada siklus I sampai dengan siklus III ialah sebagai berikut :

TABEL 5

AKTIVITAS DISKUSI PADA SIKLUS I, II DAN III

\begin{tabular}{|c|c|c|c|}
\hline \multirow{2}{*}{ Kelompok } & \multicolumn{3}{|c|}{ Nilai } \\
\cline { 2 - 4 } & Siklus I & Siklus II & Siklus III \\
\hline $\mathbf{1}$ & 2,00 & 2,40 & 3,20 \\
\hline $\mathbf{2}$ & 1,60 & 2,30 & 3,00 \\
\hline $\mathbf{3}$ & 2,00 & 2,70 & 3,30 \\
\hline $\mathbf{4}$ & 1,40 & 3,00 & 2,80 \\
\hline $\mathbf{5}$ & 1,70 & 2,50 & 3,40 \\
\hline $\mathbf{6}$ & 2,00 & 2,80 & 3,20 \\
\hline $\mathbf{7}$ & 2,00 & 3,00 & 3,50 \\
\hline Total & $\mathbf{1 2 , 7 0}$ & $\mathbf{1 7 , 7 0}$ & $\mathbf{2 1 , 9 0}$ \\
\hline Rata-rata & $\mathbf{1 , 8 1}$ & $\mathbf{2 , 6 7}$ & $\mathbf{3 , 2 0}$ \\
\hline \multicolumn{3}{|c}{} \\
\hline
\end{tabular}

Kerterangan :

Nilai akhir

$3,01-4,00=$ Sangat baik $\quad 1,01-2,00=$ Cukup

$2,01-3,00=$ Baik

Sudjana, Nana (77 : 1988)

$0,00-1,00=$ kurang

Berdasarkan nilai pada tabel 4.14 diskusi pada siklus I dapat dikategorikan masih cukup karena nilai rata-rata akhir ialah 1,81 , sedangkan pada siklus II dikategorikan baik karena nilai rata-rata akhir yang didapatkan ialah 2,67 dan pada siklus III dikategorikan sangat baik karena nilai akhir yang didapatkan ialah 3,20. Peningkatan nilai diskusi siswa pada siklus I sampai dengan III mengalami perubahan terutama pada siklus III, siswa lebih berkonsentrasi dalam diskusi pada siklus III sehingga hasil yang didapatkan pun semakin baik jika dibandingkan pada siklus I dan II.

Selain itu berdasarkan hasil observasi tentang pemebelajaran dengan media story picture di kelas VIII G motivasi siswa dapat dikatakan meningkat dari siklus I - III. Hal ini didukung dan diperkuat dari hasil wawancara dengan guru bahwa media story picture memudahkan dalam penyampaian materi, karena dalam pembelajaran siswa lebih aktif. Demikian pula pendapat siswa bahwa media selain memudahkan memahami materi, media story picture membuat pembelajaran semakin menarik dan pembelajaran PPKn tidak lagi membosankan.

\section{Kendala yang Dihadapi Dalam Proses Pembelajaran PPKn dengan Menggunakan Media Story Picture}

Penggunaan media story picture memudahkan siswa dalam memahami materi, melihat dari media yang bersifat konkrit. Namun terdapat kekurangan seperti yang dikemukakan oleh Galih Asri (2013 : 34) adalah sebagai berikut:

1. Gambar hanya menekankan persepsi indera mata

2. Gambar benda yang terlalu kompleks kurang efektif untuk kegiatan pembelajaran.

3. Ukurannya sangat terbatas kelompok besar.

Kekurangan dari media bergambar seperti yang diuraikan di atas bahwa penggunaan media bergambar sangat terbatas dalam ukurannya. Media bergambar dalam pembelajaran hanya dapat digunakan dengan ukuran bukan sebenarnya dengan skala tertentu sesuai dengan kebutuhan dan kapasitas yang ada. Berdasarkan kekurangan dari media story picture, hal tersebut menjadi kendala dalam penerapan media story picture pada proses pembelajaran.

Hal lain juga yang menjadi kendala ketika menerapkan media story picture di kelas VIII G, temuan-temuan yang terjadi selama pembelajaran diantaranya :

1. Diperlukan persiapan yang matang dari guru mitra dalam penggunaan media story picture.

2. Persiapan pembelajaran dengan menggunakan story picture cukup menyita waktu.

3. Pembelajaran PPKn dengan menggunakan media story picture bisa dikatakan cukup rumit dalam pembuatannya secara manual.

4. Ketika siswa duduk berkelompok, tak jarang menjadi kesempatan bagi siswa untuk mengobrol bersama teman yang lainnya.

Hal-hal di atas masih perlu diperhatikan kembali oleh guru. Dalam proses pembelajaran guru sebagai fasilitator yang mempunyai peranan sangat penting agar tujuan dari proses pembelajaran tercapai. Kendala yang dihadapi saat proses pembelajaran sehingga dapat diminimalisir oleh guru.

Berdasarkan hasil wawancara dengan guru mitra yang mangatakan bahwa kendala yang dihadapi yakni belum terbiasa menggunakan story picture sebagai media serta ketersediaan waktu yang kurang pada pelajaran PPKn sehingga masih banyak siswa yang mengaku belum maksimal dalam pembelajaran. Sedangkan hasil wawancara dengan siswa berpendapat bahwa kendala yang dihadapi adalah waktu yang sedikit dalam menganalisis story picture, banyak pertanyaan yang tidak selesai dijawab. Dapat disimpulkan peneliti bahwa kendala dalam pembelajaran dengan media story picture hanya waktu yang disediakan pada mata pelajaran PPKn yang kurang banyak sehingga dalam menganalisis story picture siswa dibatasi. Pelaksanaan pembelajaran PPKn dengan media story picture dengan alokasi waktu 2 jam pelajaran tidak cukup untuk mengembangkan proses pembelajaran secara optimal bagi siswa maupun guru. Hal-hal lain yang menjadi kendala penerapan media story picture ini, bisa menjadi bahan evaluasi selanjutnya.

D. Upaya yang Dilakukan Untuk Mengatasi Kendala yang Dihadapi dalam Penerapan Media Story Picture 
Melihat banyaknya kendala yang dihadapi, maka guru sebagai pengelola kelas harus dapat meminimalisir kendala tersebut, karena tugas guru selain sebagai fasilitator, guru juga harus tampil menjadi motivator, evaluator dan pengelola kelas yang baik.

Berdasarkan pengamatan peneliti di lapangan dengan melihat berbagai kendala yang dihadapi ketika penerapan media story picture, sehingga diperlukan upaya untuk mengatasi kendala tersebut. Adapun upaya yang dilakukan guru ialah sebagai berikut :

1. Guru berusaha memahami dengan benar tentang makna dan langkah-langkah pembelajaran melalui media story picture, sehingga siswa dapat lebih memahami penggunaan media tersebut.

2. Guru senantiasa meningkatkan kemampuan secara optimal dengan menambah wawasan ilmu pengetahuan baik tentang metode pembelajaran, media pembelajaran, cara pengelolaan kelas, maupun mengenai materi pembelajaran.

3. Guru berusaha menumbuhkan kepercayaan diri siswa agar lebih berani dan aktif dalam pembelajaran

4. Guru mengembangkan format RPP sesuai dengan kurikulum yang berlaku

5. Guru lebih aktif mencari referensi baik dari media cetak maupun internet mengenai materi yang akan dibahas

6. Guru memanfaatkan alokasi waktu 2 jam pelajaran dalam pembelajaran dengan menggunakan media story picture.

Beberapa upaya di atas telah dilakukan guru mitra untuk memperbaiki kendala yang dihadapi ketika menerapkan media story picture. Upaya tersebut dapat mengatasi kedala yang ada selama pembelajaran PPKn. Guru mitra dapat memposisikan dirinya dengan baik ketika pembelajaran, dengan melakukan upayaupaya tersebut kendala yang terjadi tidak membuat guru mitra merasa kesulitan dalam menerapkan media story picture tersebut.

\section{KESIMPULAN DAN SARAN}

Berdasarkan hasil analisis, refleksi, diskusi balikan, serta rencana tindakan yang telah dilakukan pada setiap siklus, mulai dari siklus I sampai siklus III pada pembelajaran PPKn yang dilaksanakan di kelas VIII G SMP Negeri 1 Cikoneng Kabupaten Ciamis mengenai "penerapan media story picture untuk meningkatkan motivasi belajar siswa dalam pembelajaran PPKn", maka secara garis besar dapat diambil beberapa kesimpulan, diantaranya sebagai berikut:

1. Sebelum menggunakan media story picture motivasi belajar siswa kelas VIII G sangat kurang dalam pembelajaran PPKn. Siswa cenderung tidak memperhatikan guru yang sedang menjelaskan materi. Kurangnya peran aktif siswa salam pembelajaran PPKn menjadi salah satu permasalahan yang sering terjadi. Pembelajaran PPKn menjadi sangat membosankan karena aktivitas siswa yang hanya duduk diam mendengarkan guru menjelaskan materi. Penerapan media story picture di kelas VIII G untuk meningkatkan motivasi belajar menjadi solusi yang dilakukan peneliti beserta guru mitra untuk mengatasi permasalahan-permasalahan ini.

2. Perencanaan yang dilakukan guru untuk mengimplementasikan pembelajaran PKn dengan menggunakan media story picture untuk meningkatkan motivasi belajar siswa dalam pembelajaran PPKn yaitu meliputi penyusunan silabus dan Rencana Pelaksanaan Pembelajaran (RPP) sesuai dengan langkah-langkah dalam pembelajaran dengan menggunakan media story picture. Pelaksanaan tindakan ini dilakukan hanya sampai tiga siklus, karena dalam siklus ketiga peneliti menganggap bahwa pelaksanaan Penelitian Tindakan Kelas (PTK) telah mencapai hasil yang sesuai dengan tujuan yang diharapkan yaitu meningkatkan motivasi belajar siswa. Pada Pelaksanaan siklus I belum ada perubahan yang terlihat pada kelas VIII G, hal tersebut dikarenakan belum terbiasanya guru mitra dalam menggunakan media yang baru yaitu media story picture. Pada pelaksanaan siklus II sudah mulai ada peningkatan dibandingkan siklus I, siswa sudah mulai terihat aktif dalam proses pembelajaran. Siklus terakhir perubahan aktifitas siswa dalam Pembelajaran PPKn sudah mulai meningkat, dilihat lebih dari setengah jumlah siswa kelas VIII G termotivasi dalam proses pembelajaran. Selain dari aktifitas siswadalam proses pembelajaran, siswa menjadi termotivasi dalam mengerjakan tugastugas yang diberikan oleh guru mitra, sehingga dapat ditarik kesimpulan motivai belajar siswa kelas VIII G meningkat setelah diterapkannya media story picture.

3. Kendala yang dihadapi dalam menerapkan media story picture adalah sebagai pembuatan media story picture yang tidak mudah, sehingga membutuhkan persiapan yang matang. Selain itu keterbatasan waktu dalam proses pembelajaran, karena penggunaan story picture sebagai media pembelajaran membutuhkan waktu yang cukup untuk bisa mendiskusikan maksud dari materi yang terdapat dalam media story picture itu sendiri.

4. Upaya yang dilakukan guru adalah lebih kreatif dalam mempersiapkan media pembelajaran. Selain itu guru memanfaatkan waktu dengan optimal dalam pembelajaran melalui media story picture, sehingga pembelajaran dapat berlangsung secara efektif dan tujuan pembelajaran dapat dicapai terutama dalam meningkatkan motivasi belajar siswa.

Dari hasil penelitian ini, sebagai bahan rekomendasi dengan mempertimbangkan hasil temuan baik di lapangan maupun secara teoritis, maka beberapa hal yang dapat menjadi bahan rekomendasi adalah sebagai berikut:

1. Bagi Guru 
a. Guru diharapkan dapat mengkondisikan siswa di dalam kelas saat pembelajaran berlangsung. Penggunaan media perlu diperhatikan oleh guru, agar pesan yang diberikan dapat tersampaikan Selain itu, penggunaan waktu dalam pembelajaran perlu diperhatikan oleh guru, agar dapat memberikan kesempatan pada siswa untuk aktif dapat pembelajaran.

b. Guru dituntut untuk lebih kreatif lagi dalam pembuatan serta penggunaan media pembelajaran disesuaikan dengan materi pelajaran, agar siswa tidak jenuh dan termotivasi dalam belajar khususnya pada mata pelajaran PPKn.

2. Bagi siswa

a. Meskipun siswa sudah menngalami peningkatan pemahaman konsep PPKn dengan menggunakan media story picture, namun alangkah baiknya jika siswa senantiasa meningkatkan pula kemampuan belajar PPKn yaitu baik dari buku paket maupun mencari informasi dari sumber lainnya seperti televisi, surat kabar, internet dan sebagainya. Mengingat dengan diberlakukannya kurikulum 2013 siswa harus lebih aktif mencari dan menggali materi yang ada, sehingga tidak perlu harus menunggu materi yang disampaikan oleh guru.

b. Siswa diharapkan dapat lebih meningkatkan peran serta dalam proses pembelajaran, sehingga pembelajaran PPKn menjadi lebih interaktif dan siswa dapat meningkatkan keaktifannya dalam pembelajaran PPKn. Sikap "takut salah" atau "malu" ketika bertanya atau berkomentar saat pembelajaran berlangsung seharusnya dihilangkan.

3. Bagi Sekolah

Agar proses pembelajaran di sekolah menjadi lebih maksimal, maka hendaknya sekolah :

a. Lebih kebebasan yang bertanggungjawab kepada guru untuk berekspresi secara kreatif dan inovatif dalam menentukan media dan metode pembelajaran yang akan diterapkan di sekolah.

b. Meningkatkan fasilitas sarana dan prasarana yang dibutuhkan dalam rangka mengoptimalkan proses pembelajaran agar lebih berkualitas.

\section{Bagi Peneliti selanjutnya}

Bagi peneliti yang ingin meneliti tentang penggunaan media story picture, sebaiknya mengadakan penelitian lebih mendalam mengenai penerapan media story picture terhadap peningkatan motivasi, minat dan prestasi belajar siswa pada mata pelajaran PPKn.

\section{DAFTAR PUSTAKA}

[1] Arikunto, Suharsimi. Dkk. (2010). Penelitian Tindakan Kelas. Jakarta : PT Bumi Aksara Azhar, Arsyad. (2007). Media Pembelajaran. Jakarta : Raja
Grafindo.

[2] Budiningsih, Asri. (2005). Belajar dan Pembelajaran. Jakarta: PT Asdi Mahasatya

[3] Creswell. (2010). Research Design Pendekatan Kualitatif, Kuantitatif, dan Mixed. Yogyakarta:Pustaka Pelajar Depdiknas. 2006. Peraturan Menteri Pendidikan Nasional Nomor 22 Tahun 2006, tentang Standar Isi.

[4] Fathurrohman, Pupuh dkk.(2007). Strategi Belajar Mengajar. Bandung : Rafika Aditama Ganeswara dan Wilodati. Dkk. (2008). Pendidikan kewarganegaraan. Bandung : CV. Yasindo Multi Aspek

[5] Galih, Asri. (2012). Penerapan Media Story Pictures dalam Pembelajaran Membaca (Dokkai). FPBS UPI : Tidak Diterbitkan

[6] Hamalik, Oemar. (2003). Proses Belajar Mengajar. Jakarta: PT. Bumi Aksara Komalasari. ( 2010). Pembelajaran Konstektual. Bandung : PT. Refika Aditama

[7] Nurmalina \& Syaifullah. (2008). Memahami Pendidikan Kewarganegaraan.

[8] Bandung : Laboratorium Pendidikan Kewarganegaraan

[9] Moleong, J. Lexy. (2010). Metodologi Penelitian Kualitatif. Bandung : PT Remaja Rosdakarya Riyanto, Yatim. 2010. Paradigma Baru Pembelajaran. Jakarta: PT. Fajar Interprtama Sadiman, Arief S. 2011. Media Pendidikan. Jakarta : RajaGrafindo.

[10] Sadirman. (2007). Interaksi dan Motivasi Belajar dan Mengajar. Jakarta : PT. Raja Grafindo Persada

[11] Sanjaya, Wina. 2011. Perencanaan dan Desain Sistem Pembelajaran. Jakarta: PT. Fajar Interprtama

[12] Sugandi, Achmad, dkk. 2000. Belajar dan Pembelajaran. Semarang: IKIP PRESS Sugiono, Prof. Dr. (2005). Memahami Penelitian Kualitatif. Bandung : Alfabeta Sudjana dan Rivai. Dkk. (2011). Media Pembelajaran. Bandung : Sinar Baru Algesindo

[13] Sudjana, Nana. (1988). Penilaian Hasil Proses Belajar Mengajar. Bandung : PT. Remaja Rosda Karya

[14] Suprijono, Agus. (2009). Cooperative Learning Teori dan Aplikasi Pakem. Surabaya: Pustaka Pelajar

[15] Surya, H Muhamad. (2004). Psikologi Pembelajaran dan Pengajaran. Bandung : Pustaka Bani Quraisy Divisi Buku Umum

[16] Tim Penyusun Penulisan Karya Ilmiah. (2012). Pedoman Penulisan Karya Ilmiah. Bandung : UPI

[17] Wiraatmadja, R. (2007). Metode Penelitian Tindakan Kelas. Bandung: PT. Remaja Rosdakarya.

[18] Wlodkowski \& Jaynes. (2004). Hasrat Untuk Belajar. Yogyakarta : Pustaka Belajar 